\title{
A Populous, Wealthy and Thriving Port? Poole in the Mid-Nineteenth Century
}

\section{Terry McDonald}

Cet article cherche à examiner la manière par laquelle les fortunes $d u$ port anglais de Poole, un centre florissant de commerce avec la TerreNeuve (et autres régions de l'Amérique du Nord), ont commencé à changer pendant la première moitié du 19ème siècle ainsi que les réactions du port à ces changements. En particulier, l'article argue du fait que les principaux citoyens de Poole ont trouvé difficile d'accepter les réalités géographiques jusqu'à ce qu'ils furent obligés de les reconnaitre. Il argue également du fait que jusqu'à ce que des personnalités nouvelles aient assuré le fonctionnement de la ville, ce réalisme n'a pas été identifié. Enfin il suggère que la participation, longue et réussie, de Poole dans le commerce avec la Terre-Neuve était en fait une aberration car la ville était, de par sa géographie et sa taille, mieux adaptée au commerce trans-manche.

"Poole, a borough, town and sea-port, and county in itself ... in Dorsetshire; 27 miles east of Dorchester, and 108 miles west-south-west of London. A lagoon, picturesquely studded with islets, bears the name of Poole Harbour, and washes three sides of the peninsulated town." " In those few words the author of an 1844 guide to every community in England and Wales neatly described the port of Poole. This article seeks to examine the way Poole's fortunes began to change in the first half of the nineteenth century and its reactions to these changes and, in particular, will argue that its leading citizens found it difficult to accept geographic realities until they were forced upon them. It will also argue that until new men took over the running of the town, this realism was not recognised. Finally it will suggest that Poole's long and successful involvement in the Newfoundland trade was in fact an aberration in that the town was, by geography and size, better suited to cross-channel trading. Its title is therefore an ironic one and is based upon a comment made in the first edition of the town's own newspaper, in 1846. By that year the port of Poole could no longer truly be described as populous, wealthy or thriving.

Poole is located more or less half way along the South Coast of England, a mere sixty-seven miles from France, and blessed with a harbour whose circumference is in

1 A. Fullerton (pub.), The Parliamentary Gazetteer of England and Wales (London, 1844), vol. III, 641 .

The Northern Mariner/le marin du nord, XXII No. 2, (April 2012), 165-177 
excess of a hundred miles. Its only entrance, though, measures just 285 metres so that at high water the harbour resembles a huge lake. It is, according to local legend, the "second largest natural harbour in the world." "While much of it is shallow, it has the double high tides that are a feature of the sea around this part of the south coast as well as deep water channels. It was where one of these channels passed between two opposite shores that the Port of Poole was established at the end of the twelfth century. From the beginning it was always rather an isolated port in that there were no major towns nearby, but it did have an agricultural hinterland and served as an exit point for a number of products, including the wool produced in the counties adjoining Dorset such as Wiltshire and Somerset, and also from Gloucestershire.

Its original trading partners were ports that were reasonably close, on both sides of the English Channel. Cherbourg, Barfleur, St. Malo and the island of Guernsey all provided regular visitors in substantial numbers, as did the English ports of Weymouth and Lyme Regis. In the year 1505-6, the arrivals and departures at Poole were 119 native ships, four Irish, twenty-seven Channel Islands, 175 foreign and two of uncertain origin. ${ }^{3}$ By the early seventeenth century the town was "handsomely built, and well provided with shipping" and had capitalised on two nearby natural resources. ${ }^{4}$ The first was clay which was used to manufacture pipes for smoking tobacco and, in the early eighteenth century, on stone from the Isle of Purbeck which was shipped in enormous quantities to London and other southern ports for use in paving streets, courtyards and kitchens. In 1722 the town was visited by Daniel Defoe who, after commenting upon Poole's relative isolation ("South ... over a sandy, wild and barren country") went on to describe it as "a considerable sea-port, and indeed the most considerable in all this part of England for here I found some ships, some merchants and some trade; especially here were a good number of ships fitted out every year to the Newfoundland fishing, in which the Pool [sic] men are said to have been particularly successful for many years past." 5 Defoe's comments were true. Poole had, even in the early eighteenth century, become a major participant in the lucrative Newfoundland trade and it was this activity that shaped and dominated its economy for the next century and a half. As the National Directory for 1830 said, "The principal trade from Poole is to Newfoundland .... Its exports consist of provisions, nets, cordage, and all sorts of wearing apparel-in short, of commodities of every kind for the supply of Newfoundland."

During the Napoleonic Wars the Poole fleet numbered more than 350 ships directly employing over 2,000 men, the great majority of them engaged in the Newfoundland trade. ${ }^{6}$ The figures for ships entering St. John's in the year 1807 show that

2 This, as implied above, is debatable. It would appear to depend upon definitions of harbours, at what state of the tide they are measured etc. This has not prevented Poole's proud claim entering various text books.

3 Cited in Dorothy Burwash, English Merchant Shipping, 1460-1540 (Toronto, 1947), 220-2.

4 L.G. Legg, Relation of a Short Survey of the Western Counties, cited in T. Willan, The English Coastal Trade (Manchester, 1967), 155.

5 Daniel Defoe, A Tour Through England and Wales (Everyman edition; London, 1928), 209.

6 Derek Beamish et al, The Pride of Poole, 1688-1851 (Poole, 1974), 1. 
although Liverpool was home to sixty vessels, Poole (a much smaller town) was just two behind with fifty-eight. That Poole should be matching the Lancashire port reflects the artificial situation created by the war. After Poole came Greenock with thirty-nine, and the Devon ports of Dartmouth and Teignmouth with thirty-seven and thirty-four respectively. ${ }^{7}$ Large numbers of Poole ships, though, would have by-passed St. John's and proceeded directly to smaller ports such as Trinity and Fogo where the town's merchants such as the Lesters and Slades conducted the bulk of their business. The "nonmetropolitan" nature of the Poole involvement was acknowledged by the town's newspaper in 1846 which, commenting on the implications of the great fire which had recently struck St. John's, observed that "the affliction [which] has spared the outposts with which Poole is connected ... will now naturally draw to themselves some portion of the trade hitherto carried on at St. John's."

It was a triangular trade, with the Poole ships sailing for Newfoundland each spring, carrying items such as boots, shoes, clothing, most of them produced in the towns and villages of Dorset. As Davies has shown, materials necessary for ships to function came from other parts of the county:

By the 1780s about 1,800 people in Bridport and the surrounding areas found employment in the manufacture of rope, twine, and sailcloth... A large proportion of this trade found its way on to the Newfoundland ships, as indeed did the sailcloth from Beaminster, Broadwindsor, Netherbury, Stoke Abbot, Kingston and Poole, the serges from Lyme Regis and the "swanskin" flannel from Marnhull and Sturminster Newton. ${ }^{9}$

Thus, Poole and its hinterland provided its ships, sailors, and those living in Newfoundland with everything they needed with the exceptions of butter and salted pork which were collected at the Irish port of Waterford and salt from Portugal or Spain to be used for curing the cod. Once they arrived in Newfoundland, the ships would be laden with great quantities of dried, salted cod-fish and would then return to Spain and Portugal where there was a market for this product. They would eventually return to Poole with cargoes of wine or fruit.

The trade had long been the preserve of those individuals who had the initiative and the money to venture in what was a decidedly risky business. Those who succeeded gave rise to family firms of great wealth such as the Spurriers, Kemps, Garlands, Lesters and Slades, who came to dominate the town's economy and politics, especially through their membership in its Corporation. As Martin put it, "Until 1835 the English borough was governed, managed, by something like a private club ... with its own well defined rules for admission, and a fair degree of freedom under the royal licence of its charters in

7 C.N. Parkinson (ed.), The Trade Winds - A Study of British Overseas Trade During the French Wars 1793-1815 (London, 1948), 243.

$8 \quad$ Poole and Dorset Herald, 23 July 1846; Melvin Baker, "The Great St. John's Fire of 1846," Newfoundland Quarterly vol. 79, no. 1 (Summer 1983), 31-34.

9 Glanville J. Davies, "Dorset in the Newfoundland Trade," Proceedings of the Dorset Natural History and Archaeological Society vol. 101 (1979), 3. 
managing its own property." 10 The Poole merchants certainly ran the town to suit themselves, right up to the passing of the Municipal Corporations' Act in 1835. By then the Newfoundland trade was in serious trouble.

While there is evidence that the trade was already in decline before the French Wars ended, the year 1815 accelerated this for the French and Americans could again fish the Newfoundland Banks. ${ }^{11}$ The latter could also now take into the colony the goods they needed more cheaply than the English. After twenty years of near monopoly in an artificial market the Poole merchants were increasingly unable to compete with these new rivals and the number of ships leaving for Newfoundland each spring fell steadily. When John Sydenham published a history of the town in 1839 he said that: "The number of vessels belonging to Poole, now employed in the Newfoundland trade, is 70 , with an aggregate burthen of 7447 tons, and give occupation to 440 men. The amount of business carried on is not, probably, to more than one-fifth the extent of the transactions of the most flourishing time of the trade, around the year 1813."12

Yet in the 1840s, Poole was still, first and foremost, a port and despite the decline in the Newfoundland trade, its general foreign commerce continued. Its long established North American links enabled it to import timber from Québec as well as from Scandinavia, the costs generated by the greater distance being offset by not having the high import duties that Baltic timber carried. There was also a flourishing trade in grain as Fullerton's Parliamentary Gazetteer of 1844 noted: "the coasting trade is extensive and prosperous; and consists partly in the transfer of corn to London and other markets, but principally in the supply of about 120,000 tons a year of Purbeck clay to the potteries of the northern counties." ${ }^{\prime 3}$ This clay, like the previously mentioned stone, was brought across the harbour by barge from the pits and mines around Wareham to Poole where it was shipped to Liverpool, eventually reaching Stoke-on-Trent by canal. After 1840, indigenous potteries were developed, thus creating one of the few industries in the town at this time that was not maritime based. ${ }^{14}$ It was to be the first of many new industries as Poole struggled to come to terms with the social changes of the mid-nineteenth century.

In 1846 the town gained its own weekly newspaper, the Poole and Dorsetshire Herald, founded by John Sydenham and for the next few years its contents reveal its proprietor's underlying concern for Poole's future. ${ }^{15}$ Yet to judge by the statement in the

10 G.H. Martin, "The Town as Palimpsest," in H.J. Dyos (ed.), The Study of Urban History (Leicester, 1976), 157.

11 Shannon Ryan, Fish Out of Water - The Newfoundland Saltfish Trade 1814-1914 (St. John's, 1985), 36.

12 John Sydenham, The History of the Town and County of Poole (Facsimile Reprint in Poole, 1986 of the original 1839 edition), 400.

13 Fullerton, Parliamentary Gazetteer, III, 641.

14 The town's Gas and Coke Company, established in 1833, was probably the first such industry.

15 Later, on 30 May 1850, the paper became the Poole and South Western Herald, then the Poole and Bournemouth Herald in 1877. Eventually it became the Poole and Dorset Herald and remained so until the 1980 s when it was absorbed by the town's free newspaper, the 
paper's first edition on 9 April 1846, that "Poole is a populous, wealthy and thriving port, the seat of considerable commerce," it is also quite clear that Sydenham subscribed to the traditional perception of the town. It does not appear to have occurred to Sydenham that other nearby ports were all of these things and more, a point made clear when comparisons are made with the south coast's two largest ports. Although Southampton:

was considerably smaller in population than Portsmouth, and its economy was geared more strongly towards merchant shipping than the armed forces; [it] was closely connected with London, enjoying a mainline railway line before Portsmouth and indeed generating greater road traffic with the capital than Portsmouth, but like Portsmouth, Southampton was a seaport with a significant manufacturing sector, whose population also grew rapidly during the nineteenth century. ${ }^{16}$

Poole's population in 1851 was, at 8,751 , much smaller. There was only a tenuous railway connection and manufacturing was, apart from shipbuilding, virtually non-existent, although the pottery and iron-founding industries were at an embryonic stage.

The first edition of the Herald also carried an advertisement that is indicative of the changes beginning to affect the fortunes of the port of Poole. Whereas it had flourished in the age of sail, and what was left of its Newfoundland fleet was still winddriven, the steam ship was making steady inroads. Thus the Herald's advertisement for an Easter Monday excursion to Swanage by the steam packet Water Witch, a 150 ton, 70 ( 2 x 35) horsepower vessel owned and operated by The Poole, Isle of Purbeck, Isle of Wight and Portsmouth Steam Packet Company, suggests a change in both the nature of the town's ships and those who owned them. The directors of this venture included a number of men from Poole's traditional mercantile community, including two Slades and Martin Kemp Welch who had never before been involved in such parochial activities. Later that summer the Water Witch was being used for a regular twice weekly service to Portsmouth and the Isle of Wight, and for an excursion on 31 July ("wind and weather permitting") to France. She would leave Poole at $8 \mathrm{pm}$ for Cherbourg (sixty-seven miles distant) and, after the eight hour crossing, the passengers (at twenty shillings a head) would have three days in France, allowing them to sample the delights of St. Lo, Bayeux or the cathedral at Coutances. Plus ça change! This is precisely what thousands of local people were doing during the late twentieth and early twenty-first centuries when they made use of the Brittany Ferries service from Poole to Cherbourg on the car-ferry Barfleur. The only difference today is that it is usually a one-day excursion, culminating with a visit to one of the hypermarkets in order to stock up with cheap beer and wine.

Poole Advertiser. As for John Sydenham, he died very soon after founding the paper, in December of 1846, aged 39.

16 J. Field, "Wealth, Styles of Life and Social Tone. Amongst Portsmouth's Middle Class, 1800-1875," in R.J. Morris (ed.), Class, Power and Social Structure in British Nineteenth Century Towns (Leicester, 1986), 75. By 1861 Southampton's population had reached 46,960 against Portsmouth's 94,799. Poole, in 1861, had yet to make five figures, standing at 9,750 . 
This is not as flippant a point as it may seem — what was happening is that Poole was, perhaps by default, giving in to geographical and commercial realism. Another modern parallel was the decision in September 1847 to use the Water Witch to provide a regular service to the Channel Islands - today Poole is a major port for this service. Yet Water Witch was too small for such cross-channel services and so, in February 1848, she was offered for sale. ${ }^{17}$ The company was dissolved at the end of October and the $£ 700$ left over after all claims had been met were "divided between the proprietors, according to their share." 18

It was of course natural that Poole's entrepreneurial class should look first to the harbour and the open seas as a way of creating wealth for that was the way it had always been done. The shipping lists published each week in the Herald do reveal a comparatively busy port with, for example, thirty-one arrivals and sixteen departures during the week in which the newspaper first appeared. Almost all of them, though, were involved in the coastal trade although one ship sailed that week with general cargo for Newfoundland. In the edition of 14 May 1846, three ships sailed for the same destination, two of them carrying cargoes of salt. The Atlantic still exerted a considerable hold on the town with one member of the Adey family regularly advertising passages to Quebec on his "fast sailing ship" Delia of 573 tons. She usually made two trips a year, leaving Poole in March and July and returning with timber. The timber trade between Britain and Quebec was buoyant at this time because Baltic timber still carried high import duties. Indeed, the Atlantic had become doubly profitable to ship owners thanks to the carriage of passengers, overwhelmingly emigrants to Upper Canada, on the outward voyage. Yet Poole's links with North America and other distant regions were slowly being severed. The phenomenon of large-scale emigration, especially the "parish sponsored" emigrations to Canada in the 1830s, seldom involved Poole, the preferred southern ports being Bristol and Portsmouth. Its long-term future, if it was to have one, was to be based upon English Channel trade rather than the North Atlantic. Thus, in the 1840 s, a number of interesting schemes were proposed and (in some cases) introduced, some of them involving the new railway company.

Poole desperately needed a railway. As a town built upon a peninsula, it was being by-passed as the new railway lines were developed, especially those from London to the West of England. The longer the town was without a railway the greater the danger to the port that cargoes entering or leaving by sea would cease to be economical if transported by road. Eventually, in 1847, the railway did arrive, but in a far from satisfactory manner. The Southampton and Dorchester Company built a branch line to Poole but placed the terminus in Hamworthy, on the southern side of the Quay, thus necessitating that traffic cross a toll-bridge in order to reach the town proper and the centre of its commercial and shipping activities. It was to be another twenty-five years before a station and a new line were built within the town.

The Railway Company had been approached by the directors of The Poole, Isle

17 She was used on a cross-Bristol Channel service in 1849.

18 Poole and Dorsetshire Herald, 21 December 1848. 
of Purbeck, Isle of Wight and Portsmouth Steam Packet Company to help them instigate a new service to the Channel Islands. The Town Council became involved and promised a new mooring on the Quay and a new crane. The venture was called the New SouthWestern Steam Navigation Company and, at the end of April 1848, the new service began. "London to the Channel Islands via Poole in eleven hours!" trumpeted the advertisements in the Herald adding that the actual sea crossing would "not exceed five hours and a half."19 Three weeks later the advertisement was amended by adding an hour to the total travelling time.

The use of Poole as the port of departure made geographic sense, for the maritime section of the journey for Jersey is only 104 nautical miles distant. The rail connections, however, were a different matter. There was the new line into Hamworthy but this did not offer passengers much in the way of comfort and convenience. As one irate passenger wrote in a letter to the Herald in 1850, "I have travelled over most lines but I cannot recall to my recollection so utterly wretched a station." 20 That newspaper was even stronger in its condemnation of the line and its facilities, describing it as "The wretched abortion which connects Poole with the direct London rail."21

Herein lay the problem. As a railway historian noted, "the situation in Poole was an almost exact counterpart to that of Portsmouth in that this ancient seaport standing on a fine harbour, was served no more than indirectly by a branch line from Hamworthy, on the wrong side of Poole Harbour. Poole itself had to be reached by ferry, and to reach Bournemouth one had to charter some road conveyance from Poole."22 The inconvenience was too much for the New SouthWestern Steam Navigation Company. Its weekly advertisement in the Herald failed to appear in the 2 November 1848 edition and letters condemning the company and its threatened removal of the service to Southampton were published in the following weeks.

Over the next few years Poole fought hard to re-establish itself as a steam-packet port and to improve its rail connections. Some of its attempts smack of desperation, particularly one which proposed that it should act as a lynch-pin in a London-Cornwall steam service. The plan was for passengers to travel from London to Poole by train, and to travel on by sea to Penzance. Despite support in both ports, this scheme came to nothing.

Another scheme for re-vitalising the port was one which had been suggested half a century earlier, namely to link the Bristol and English Channels with the exit to the latter being Poole Harbour. The original plan was to link them by canal but in the $1850 \mathrm{~s}$ it was the South Midland Union Railway that sought to finance its plans to carry coal and steel from South Wales to Poole Harbour and then on to Cherbourg. This required an investment of $£ 1$ million and this proved to be too much. In 1853 the Bill promoting this

19 Poole and Dorsetshire Herald, 27 April 1848. A first-class return, rail and sea, cost thirtyfive shillings, with third class passengers paying twenty shillings six pence. The Company also offered onward travel in its own vessels from Jersey to Granville and St. Malo.

$20 \quad$ Poole and South Western Herald, 20 June 1850.

21 Poole and South Western Herald, 29 August 1850.

22 O.S. Nock, The London and South Western Railway (Newton Abbot,1965), 53. 
scheme was abandoned.

The problems facing the port were not always economic ones; nature was also intervening in such a way that the harbour was in danger of becoming unusable to commercial shipping. It was silting up and the Herald saw this as the major issue for the town at the beginning of the 1860s, devoting an entire page to what it termed "The Poole Harbour Question" in its first edition of the new decade. Supporting the view that the harbour was essential, not only to Poole's prosperity but also to all the neighbouring towns such as Wimborne and Blandford, it analysed the findings of various surveys taken over the past few years as to the state of the channel into and through the harbour. Between 1849 and 1858 the entrance to the channel had contracted from 160 fathoms to 120 fathoms and, when tides were at their lowest, there was only ten feet of water at the bar. "We are at the Rubicon," said the Herald, "Poole must now regenerate or it never will be." 23

Establishing Poole as a major cross-channel port was an obvious part of this regeneration and this was attempted again in 1865 when a regular service to Cherbourg began under the auspices of the recently created Somerset and Dorset Joint Railway. The old dream of linking Poole Harbour with the Bristol Channel finally came about when the Somerset Central Railway, whose line ran from Burnham-on-Sea to Cole, near Bruton, amalgamated with the Dorset Central Railway in 1862. Their line ran from Cole to Wimborne. At Wimborne the Somerset and Dorset trains used the London and South Western Railway's station and, by reversing, could continue on the branch line to Hamworthy.

The inaugural trip to Cherbourg by the steamship Albion took place on 12 June 1865 and, in a speech at a "Grand International Banquet" in the French port, one of Poole's two MPs, Henry Danby Seymour, said that he hoped "our steamship line will serve two ends; firstly that it will supply the local needs of the prosperous counties and departments on either side of the Channel, and secondly, that it will provide a new line of communication between the great industrial centres of both countries." 24 At a second banquet, this time in Poole in September where thirty-two members of the Municipality of Cherbourg were entertained, a speech was given by Richard Sydenham, younger brother of the Herald's first owner and editor, which reveals the sense of irritation felt in Poole at its declining importance as a port. Extolling the virtues of the new service, he maintained that: "It gave to invalids the opportunity of reaching by easy journeys the different convalescent resorts on both sides of the channel, protected from the rapid currents, annoyances of change of vessel, irregularities, delays and discomforts of the passage by the Channel Islands to St. Malo." Then, in a pointed reference to Poole's eastern rival, he noted that: "the distance was little more than half, and in every way pleasanter, than the fashionable Southampton-Le Havre route." 25

The service seemed successful at first, offering a "New and Cheap route to Paris, 
Bordeaux and the South of France" twice a week with the sea passage taking six hours ("wind and weather permitting"). A one-month return ticket from Poole, to Paris, second class and with an aft cabin cost 49/10d. ${ }^{26}$ Yet the service barely lasted a year; by August 1866 the directors were having to consider whether Albion should be laid up during the winter months (or chartered elsewhere) and in February 1867 the company announced that the service was "for the present, suspended, the operation having hitherto resulted in a loss." 27

One railway historian suggests that the problems were "primarily geographical - and hence to some extent financial ... the Somerset and Dorset Railway was not connected, because the Mendip Hills were a natural barrier, to lines to Bristol and the North, a principal selling point for the service." ${ }^{28}$ A Poole historian, though, puts part of the blame on a "lack of foresight on the part of the Poole Harbour Commissioners ... and disputes concerning the payment of harbour dues etc." 29 Whatever the reason, this was not the last attempt at offering a regular service to France for another was made almost immediately. In May a company was established to raise $£ 20,000$ by issuing eight hundred shares at $£ 25$ each and by the end of the month the Herald was proclaiming that "only about 100 shares were unallotted." 30 A week later it was proudly announcing that the steamship Spicy had been purchased and that Captain Stephen Adey was to be her Master. This was the same Stephen Adey, Master of the Delia, whose passages to Québec had helped maintain Poole's North American connections and there is perhaps something symbolic in his change of command. He and his chosen crew travelled to Liverpool and brought Spicy to Poole, arriving on Sunday 16 June. She was 164 feet long and capable of speeds in excess of eleven knots and was described as "a very handsome paddle-boat." 31 It appears to have been a good investment, with the Poole Pilot saying that "The shareholders of the new company may also be congratulated ... on the possession of such a suitable vessel as the Spicy on such economical terms." 32

She sailed for Cherbourg the next day, returning to Poole "heavily laded with potatoes, butter, eggs, poultry, fruit etc." Most of the cargo was sent to London although some went to Poole traders. ${ }^{33}$ She was still sailing in December but by August of the following year was being used for excursions from Bournemouth to Swanage, a sure sign of impending trouble. ${ }^{34}$ A month later the Pilot was reporting that "Trade between France and Poole is now remitted to the gloom of an indefinite, vast and improbable future." 35

26 From the company's regular advertisement in the Herald and cited in Mathews, Gallant Neighbours, 171.

27 R. Atthill, The Somerset and Dorset Railway (Newton Abbott, 1967), 45.

28 Atthill, Railway, 45.

29 Mathews, Gallant Neighbours, 156.

$30 \quad$ Poole and South Western Herald, 30 May 1867.

$31 \quad$ Poole and South Western Herald, 20 June 1867.

32 The Poole Pilot, 1 August 1868 [sic?].

33 Poole and South Western Herald, 27 June 1867.

34 The Poole Pilot, 1 August 1868.

35 The Poole Pilot, 1 September 1868. 
In May 1869 it had to announce that Cherbourg was "lost to Poole" as the South Western Railway Company had begun a steamship service to that port from Southampton. "Poole," it said, "was handicapped by its vicious railway system." 36

Why should all these attempts to carve out a new role for Poole and its harbour fail? An obvious answer is the human failings of those running the town. Earlier, mention was made of the nature of the town's Corporation and the fact that it had long been dominated by men of a mercantile background, particularly those with a connection to the Newfoundland trade. Before 1835, when the Municipal Corporations Act brought a semblance of democracy to English local government, Poole had been run by a selfperpetuating oligarchy of Newfoundland merchants and their relations. As late as 1830 , the Corporation, which had no prescribed size, made the decision to enlarge itself, presumably to raise money. The forty-eight men who comprised the Corporation at that time were each allowed to nominate two new members at a cost of $£ 25$ each and all of them took advantage of this opportunity. It therefore expanded to ninety-one resident and seventy-one non-resident members (or "burgesses"), of whom most were still overwhelmingly connected to the Newfoundland trade. The Slade family, for example, traditionally the "millionaire" firm of Newfoundland traders, had eleven members, five of them minors. All but two of them were members of merchant and ship-owning families, along with naval officers, customs officers, bankers, surgeons and gentlemen. While obviously not all of these were involved in the Newfoundland trade, the great majority were.

In 1835 this unwieldy Corporation, whose duties were mainly confined to appointing the town's few officials, eating the occasional dinner and (until 1832) voting in Parliamentary elections, was reduced to just twenty-four men - eighteen councillors and six aldermen. The former were elected, the latter appointed. Despite this reduction, the new "Council" retained its mercantile appearance:

Councillors:

Robert Slade, Merchant

George Welch Ledgard, Banker

Robert Slade [sic], Merchant

Robert Slade [sic], Merchant ${ }^{37}$

George Holland, Coal Merchant

John Adey, Wine Merchant

William Adey, Brewer

Samuel Clark, Wine Merchant

Thomas Slade, Merchant

William Green, Gentleman (ex-Baker and Confectioner)

Francis Timewell Rogers, Tanner

Richard Pinney, Coal Merchant

Robert Major, Merchant and Rope-maker

36 The Poole Pilot, 1 May 1869.

37 The Slades would appear to have been an unimaginative family when it came to choosing Christian names. 
Richard Stanworth, Ship Owner

George Lockyer Parrott, Gentleman (ex-Master-Mariner)

Thomas Rickman, Corn Factor

George Ledgard, Banker

Tito Durell Hodges, Currier

plus six Aldermen:

Robert Slade, Merchant (one of the above)

David Osmond Lander, Collector of Customs

George Ledgard (see above)

George Hancock, Coal Merchant

Thomas Gaden, Coal Merchant

Joseph Barter Bloomfield, Merchant. ${ }^{38}$

Of the men in this list, only the baker and confectioner William Green and the tanner Francis Timewell Rogers were not merchants in the sense that the term was still used in Poole. The currier, Tito Durell Hodges, was also elected but his middle name clearly reveals his mercantile connections whilst the "gentleman," George Lockyer Parrott, had a seafaring background as mate and master on ships engaged in the Newfoundland trade, including those of the Adeys.

By 1865, when the town was seeking new ways of utilising its harbour and port, the Council had taken on a markedly different complexion:

Councillors:

Charles Augustus Lewin, Timber, Deal and Slate Merchant

George Hancock Gutch, Coal Merchant

Christopher Hill, Corn Merchant

James Jarvis, Draper

William Lewis Cockram Adey, Coal Merchant

George Frampton, Coal Merchant

John Sidney Hudson, Pottery Manager

George Robert Penney, Line, Twine and Sailcloth Manufacturer

Joseph Harker, Solicitor

George Anthony Adams, not known

Frederick Styring, Brewer

Francis Timewell Rogers, Gentleman, Landed Proprietor (ex-tanner)

George Belben, Miller

Thomas Ruckman, Jnr., Brewer and Maltster

Henry Harris, Timber and Slate Merchant

Edward Mullett, Corn Merchant

James Wood, Coal Merchant

William Ruckman, Corn Merchant

plus six Aldermen:

James Kemp, Esquire (ex-merchant)

38 Two of the aldermen, Robert Slade and George Ledgard, had already been elected as councillors, hence the duplication of their names. 
John Gosse, Merchant

John Adey, Wine and Brandy Merchant

Isaac Steele, Esquire (Merchant family)

Thomas Wanhill, Ship Builder

William Pearce, Ironfounder

The difference between the two councils is a rather subtle one, and depends mainly upon the meaning of the word "merchant." This can be clarified by making use of the categories traditionally used to delineate where a Master of a vessel was allowed to venture, according to the level of his professional qualification. Thus there were "deep sea," "near continental," and "home trade" categories with the first and third being selfexplanatory. "Near continental," though, covered an area from "Brest to the Elbe" and thus allowed masters to venture into the English Channel and North and Irish Seas, i.e. out of sight of land.

In 1835 eleven members of the council were merchants or had mercantile connections that can be categorised as "deep sea" while five were "home trade" or "near continental." There were four "manufacturers" and two "others." In 1865, using the same broad descriptions, only one man, John Gosse, came into the "deep sea" category, but the "home trade" and "near continental" categories had risen to ten. There were four "manufacturers" and six "others," a group which included two "esquires" and the elusive George Anthony Adams.

A second indicator of the declining influence of "deep sea" trading at this time is the number and type of vessels in port on Census night, 1861. Four of the thirty-one were foreign, from Italy, Hanover, Norway and Sweden, but the other twenty-seven were British. Only one of these, the 550-ton Gartcraig of Poole, with a crew of fifteen and sailing to Québec, was an ocean-going vessel. The other British ships were much smaller, ranging from seventeen to 181 tons. The mean tonnage was sixty-nine, but eleven were less than fifty tons. Even more revealing is where the vessels had come from. Sixteen were from the south coast of England, including six from Portsmouth and three from Southampton, while of the others the most distant ports were Goole and Amwlch in Anglesey. There was one from Jersey. Thus the great majority of Poole's sea-borne trade by the 1860 s was not "deep sea" but mainly "coastal" with some "near continental."

There is one last piece of qualitative evidence to support the suggestion that, by the 1860s, Poole's "deep sea" mercantile era was over. This was the collapse of Ledgard's bank in February 1861. The bank had been established by George Welch Ledgard and Martin Kemp Welch in 1821 as "Poole Town and County Bank" in the High Street, and at the time of the collapse they had a branch in Ringwood. Their middle names reveal that both founders had strong mercantile connections.

The impact of the collapse was so momentous that for the first time since its creation in 1846, the Herald brought out a special single page edition; this was on Monday 18 February. It reported in full on the meeting of the creditors, an event that attracted so many people (more than two hundred) that it had to be moved from its original venue at the London Hotel to the Guildhall. There it was revealed that the bank 
had liabilities of $£ 92,68714 \mathrm{~s} 11 \mathrm{~d}$ but assets of only $£ 61,06710 \mathrm{~s} 7 \mathrm{~d}$. It was reckoned that another $£ 10,000$ could be found from the sale of the family's two private estates, creating total assets of $£ 71,000$. The Herald then added that "This amount is independent of a sum of nearly $£ 20,000$ due to the bank by Messrs Robert and James Slade trading as Executors of Slade, which firm has suspended payment." Thus, not only had the Poole merchants' bank collapsed, it was the archetypal Newfoundland merchant family that had caused it. ${ }^{39}$

Fundamental change can rarely be pinned to a specific event. Instead it is usually a matter of the steady erosion of old forces by new ones. This, it is argued, was the case in Poole where the old forces were its merchants. The town had flourished as a port for the Newfoundland (and other parts of North America) trade for over two hundred years, its ruling, mercantile class revelling in its relative isolation and independence. The early stages of industrialisation made little difference to its economy and social hierarchy but its merchant class failed to come to terms with changes being forced upon their town by geography, ship technology and public attitudes and tastes. Eventually this traditional mercantile elite was replaced by shopkeepers and manufacturers who had little appetite for attempts to recreate the "golden age" of the late eighteenth, early nineteenth centuries. Today this "golden age" can be seen as something of an aberration for Poole was never again to be the "populous, wealthy and thriving port" described in the first edition of the Poole and Dorsetshire Herald. Or perhaps it is, for the town today has a population of 140,000 , a diversified economy, some of the most expensive housing in the country, and, (ironically) a cross-channel (passenger and freight) service to Cherbourg and the Channel Islands. It only required another hundred years, from the 1860 s to the 1960 s, to reach this state.

39 The collapse of Ledgard's turned out to be less severe than originally feared and eventually the creditors received $17 / 6 \mathrm{~d}$ in the pound. 
